\title{
Universiteit
}

Leiden

The Netherlands

\section{The Polycomb group protein Ring1b is essential for pectoral fin development}

Velden, Y.U. van der; Wang, L.; Lohuizen, M. van; Haramis, A.

\section{Citation}

Velden, Y. U. van der, Wang, L., Lohuizen, M. van, \& Haramis, A. (2012). The Polycomb group protein Ring1b is essential for pectoral fin development. Development, 139(12), 2210-2220. doi:10.1242/dev.077156

Version: $\quad$ Not Applicable (or Unknown)

License: $\quad$ Leiden University Non-exclusive license

Downloaded from: https://hdl.handle.net/1887/45202

Note: To cite this publication please use the final published version (if applicable). 


\title{
The Polycomb group protein Ring1b is essential for pectoral fin development
}

\author{
Yme U. van der Velden, Liqin Wang, Maarten van Lohuizen and Anna-Pavlina G. Haramis*,‡
}

\begin{abstract}
SUMMARY
Polycomb group (PcG) proteins are transcriptional repressors that mediate epigenetic gene silencing by chromatin modification. PcG-mediated gene repression is implicated in development, cell differentiation, stem-cell fate maintenance and cancer. However, analysis of the roles of PCG proteins in orchestrating vertebrate developmental programs in vivo has been hampered by the early embryonic lethality of several PcG gene knockouts in mice. Here, we demonstrate that zebrafish Ring1b, the E3 ligase in Polycomb Repressive Complex 1 (PRC1), is essential for pectoral fin development. We show that differentiation of lateral plate mesoderm (LPM) cells into presumptive pectoral fin precursors is initiated normally in ring $1 b$ mutants, but fin bud outgrowth is impaired. Fgf signaling, which is essential for migration, proliferation and cell-fate maintenance during fin development, is not sufficiently activated in ring $1 \mathrm{~b}$ mutants. Exogenous application of FGF4, as well as enhanced stimulation of Fgf signaling by overactivated Wnt signaling in apc mutants, partially restores the fin developmental program. These results reveal that, in the absence of functional Ring1b, fin bud cells fail to execute the pectoral fin developmental program. Together, our results demonstrate that PcG-mediated gene regulation is essential for sustained Fgf signaling in vertebrate limb development.
\end{abstract}

KEY WORDS: Ring1b, Zebrafish, FGF signaling, Fin, Polycomb

\section{INTRODUCTION}

Polycomb group $(\mathrm{PcG})$ proteins are transcriptional repressors that act as crucial regulators of differentiation, proliferation, DNA repair and cell-fate maintenance during embryonic development and in adult tissue homeostasis (Bracken and Helin, 2009; Gieni and Hendzel, 2009; Sauvageau and Sauvageau, 2010; Sparmann and van Lohuizen, 2006; Surface et al., 2010). PcG proteins form multimeric protein complexes that mediate epigenetic gene silencing through multiple mechanisms, including the organization of higher-order chromatin structure, post-translational modifications on nucleosomes and interference with the transcription machinery (Eskeland et al., 2010; Sparmann and van Lohuizen, 2006; Stock et al., 2007; Surface et al., 2010; Vire et al., 2006; Zhou et al., 2008). PcG protein-mediated epigenetic modification of histones is probably the best characterized PcG function. Polycomb repressive complex 2 (PRC2) mediates trimethylation of histone $\mathrm{H} 3$ at lysine 27 (H3K27) through the action of the histone methyltransferases EZH1 and EZH2 (Cao et al., 2002; Czermin et al., 2002; Kuzmichev et al., 2002). This epigenetic mark is recognized by the chromodomain of Polycomb (Camarata et al., 2010) in the Polycomb repressive complex 1 (PRC1). Recruitment of PRC1 results in the mono-ubiquitylation of histone $\mathrm{H} 2 \mathrm{~A}$ at lysine 119 through the E3 ligase activity of RING-domain-containing proteins (de Napoles et al., 2004; Wang et al., 2004). In addition, Ring $1 \mathrm{~b}$ can participate in several PRC1like complexes (Gao et al., 2012) and PRC1 can be found at chromatin independently of PRC2 (Trojer et al., 2011). Two orthologs of the Drosophila E3 ligase dRing, Ring1a and Ring1b,

Department of Molecular Genetics, Netherlands Cancer Institute, Amsterdam, The Netherlands.

*Present address: Institute of Biology Leiden (IBL), Leiden University, Sylvius Laboratory, Leiden, The Netherlands

‡Author for correspondence (a.haramis@nki.nl)

Accepted 3 April 2012 are found in mammals and amphibians, whereas only a single gene that is most homologous to Ring1b has been identified in zebrafish (Le Faou et al., 2011; Vidal, 2009).

Analysis of the roles of Ring1b in orchestrating differentiation programs during vertebrate development has been hampered because disruption of Ring $1 b$ (Rnf2 - Mouse Genome Informatics) in mice leads to an arrest at gastrulation (Voncken et al., 2003). To address the function of Ring $1 \mathrm{~b}$ in vertebrate development, we turned to zebrafish. In zebrafish, owing to external fertilization and optical clarity of the embryos, development can be followed from very early stages and, thus, even an early phenotype is informative. Furthermore, in zebrafish, maternal contribution of several crucial factors enables the completion of gastrulation, despite harboring mutations in embryonic essential genes. This provides the unique opportunity to investigate gene regulation mechanisms in early and late developmental processes in an unbiased manner.

In this study, we generated Ringlb-deficient zebrafish and uncovered an essential function for Ring1b (Rnf2 - Zebrafish Information Network) in pectoral fin development. The development of the vertebrate limb bud is a tightly regulated developmental program that is well conserved from fish to tetrapods. Pectoral fin bud outgrowth depends on epithelial-mesenchymal communication; proliferation and differentiation need to be coordinated as the limb grows, and fin morphogenesis involves the orchestrated action of several intertwined molecular networks.

Establishment of the fin field by axial signals is controlled by retinoic acid (RA) signaling. RA is synthesized mainly by aldehyde dehydrogenase 1 family member a2 (Aldh1a2) in the anterior somites (Begemann et al., 2001; Grandel et al., 2002). In response to RA signaling, wnt $2 b a$ expression is initiated in the intermediate mesoderm ( $\mathrm{Ng}$ et al., 2002). In turn, Wnt2ba is required for expression of the T-box transcription factor $t b x 5$ in the lateral plate mesoderm (LPM) (Neto et al., 2012). Between the 6- and 15somite stages (ss; 12-16 hours post-fertilization, hpf) (Kimmel et al., 1995), tbx5-positive cells comprise two bilateral stripes that contain both heart and fin precursors (Ahn et al., 2002; Begemann 
and Ingham, 2000; Furthauer et al., 2001). From 15 ss onwards, heart precursors migrate medially to form the heart tube at the 20 ss (19 hpf). The more posteriorly located fin precursors condense into a compact fin field. Notably, $t b x 5$ is the earliest known marker of prospective pectoral fin mesenchyme and is essential for the migration of these precursors (Ahn et al., 2002).

Fin-mesenchyme compaction proceeds through Tbx5-mediated activation of fibroblast growth factor 24 (Fgf24), a teleost-specific Fgf and the first family member to be expressed in the pectoral fin mesenchyme (Fischer et al., 2003). Fgf24 signaling is required for both maintaining $t b x 5$ expression and inducing $f g f 10$ expression in the LPM cells, possibly through binding to Fgf receptor 2 (Fgfr2) (Fischer et al., 2003; Harvey and Logan, 2006). In turn, Fgf10 maintains $f g f 24$ expression and contributes to the induction of the apical ectodermal ridge (AER), a signaling center that promotes outgrowth of the pectoral fin, starting at $28 \mathrm{hpf}$ (Norton et al., 2005). Fgf10 signaling is then uniquely required for maintenance of AER function. Notably, $f g f 24$ expression in the fin mesenchyme is downregulated at around $32 \mathrm{hpf}$, and ectodermal expression commences (Fischer et al., 2003). AER-derived Fgfs signal back to the pectoral fin mesenchyme to maintain $f g f 10$ expression, thereby creating a positive-feedback loop in order to sustain $t b x 5$ expression and further fin outgrowth (Fischer et al., 2003; Nomura et al., 2006; Norton et al., 2005).

Here, we show that pectoral fin development is initiated normally in Ringlb-deficient zebrafish embryos. Pectoral fin precursors express $t b \times 5$ and are located at the correct position during somitogenesis in ring $1 b$ mutants. However, RA signaling is upregulated after somitogenesis and Fgf signaling is never fully activated. Indeed, we show that enhanced Fgf signaling partially rescues the defects in pectoral fin development. This demonstrates that the PcG protein Ring $1 \mathrm{~b}$ coordinates the evolutionary conserved pectoral fin program via regulation of the Fgf-signaling pathway.

\section{MATERIALS AND METHODS}

\section{Zebrafish strains and genotyping methods}

Zebrafish were maintained as previously described (Westerfield, 2000). Fish were cared for in accordance with institutional guidelines and as approved by the Animal Experimentation Committee of the Royal Netherlands Academy of Arts and Sciences. Ring $1 b$ founder fish were out-crossed to AB and TL genetic backgrounds. Genotype analysis was performed by PCR using the primer set ring1b_F (AGGAGTGTCCAACATGCAGAAAG) and ring1b_R (GAGGATTTGTAACAAAGCCGC), followed by sequence analysis for the ring $1 b^{+4}$ allele or digestion of the PCR product with restriction enzyme Taq1 to identify the ring $1 b^{\Delta 14}$ allele.

\section{Sample preparation and western blot analysis}

Histone extracts were prepared by lysis of 60 embryos per tube in 5\% perchloric acid containing Complete protease inhibitor cocktail tablets (PIC, Roche), $1 \mathrm{mM}$ PMSF and $10 \mathrm{mM}$ iodoacetamide. To extract core histones, the pellet was resuspended in $0.4 \mathrm{~N} \mathrm{HCl}$ containing PIC, $1 \mathrm{mM}$ PMSF and $10 \mathrm{mM}$ iodoacetamide, and incubated overnight at $4{ }^{\circ} \mathrm{C}$ while rotating. Samples were centrifuged and the pellet discarded. Core histones were precipitated by the addition of one volume of ice-cold trichloroacetic acid and washed with ice-cold acetone containing $0.006 \% \mathrm{HCl}$. The pellet was washed in ice-cold acetone and vacuum dried, then solubilized in 50 $\mathrm{mM}$ Tris- $\mathrm{HCl}(\mathrm{pH} 7.5)$.

To detect endogenous Ring1b, 30 embryos per tube were lyzed in 100 mM PIPES (pH 6.8) containing $1 \mathrm{mM}$ EGTA, $1 \mathrm{mM} \mathrm{MgCl}$, PIC, $1 \mathrm{mM}$ PMSF and $1 \mathrm{mM}$ DTT. TritonX-100 (3.5\%) was added after 5 minutes. Samples were centrifuged and pellets resuspended in RIPA lysis buffer containing PIC, $1 \mathrm{mM}$ PMSF and $1 \mathrm{mM}$ DTT. Samples were sonicated for 5 minutes ( $210 \mathrm{~W}, 30$-second pulse) and after centrifugation, supernatant was collected. To detect myc-tagged Ringlb, 5 embryos per tube were lyzed in RIPA lysis buffer containing PIC, $1 \mathrm{mM}$ PMSF and $1 \mathrm{mM}$ DTT. Samples were centrifuged and supernatant collected.
Protein extracts were separated on $4-12 \%$ bis-Tris precast gels (NuPAGE) and transferred to Immobilon-P membranes (Amersham Biosciences). Primary antibodies used were: mouse anti- $\beta$-actin (1:5000; ab6276, Abcam), rabbit anti-c-myc (1:1000; SC789, Santa Cruz), rabbit anti-H2A (1:1000; 07-146, Millipore) and rabbit anti-H3 (1:1000; ab1791, Abcam). Ring1b rabbit polyclonal antibodies were obtained from $\mathrm{M}$. Dyers. Secondary antibodies used were goat anti-mouse $\operatorname{IgG}(1: 10,000$; Zymed) and goat anti-rabbit IgG (1:10,000; BioSource).

\section{Generation of expression vectors}

ZFNs were generated essentially as described previously (Carroll et al., 2006). The DNA sequence encoding both zinc fingers was obtained from Geneart and cloned into pENTR-NLS-G-FN using NdeI and SpeI restriction sites. This construct was shuttled into the pCS2-DEST expression vector using the Gateway cloning system (Invitrogen). To generate the ring $1 b$ expression construct, the open reading frame of $r i n g 1 b$, excluding the $5^{\prime}$ and $3^{\prime}$ untranslated regions, was cloned into pCS2+-Myc using BamHI restriction sites.

\section{mRNA and morpholino injections}

Vectors were linearized with NotI. Capped mRNA was synthesized using the SP6 mMessage mMachine kit (Ambion). mRNA (100 pg) encoding each ZFN and 25-500 pg ring $1 b$-myc mRNA was injected into one-cell stage zebrafish embryos. Morpholinos against ring $1 b$ were obtained from Gene Tools (Oregon, USA). ATGMO1 (5 ng) (ACACCACGTCTTTTATCTCAATGTT) and $20 \mathrm{ng}$ of splice-blocking MO2 (TTAATAACTCAAACAAACCCTGATC) were injected into fertilized oocytes.

\section{Whole-mount in situ hybridization}

Whole-mount in situ hybridizations were carried out according to a standard protocol (Westerfield, 2000). BM purple and INT/BCIP (Roche) were used as alkaline phosphatase substrates. Probes for axin2, $f g f 8$, myca and $s h$ have been described previously (Haramis et al., 2006; Krauss et al., 1993; Reifers et al., 1998). Antisense riboprobes amplified from cDNA were dhrs3, dusp6, engla, hoxa9b, hoxb5b, hoxc6a, hoxc8a, hoxd9a, meis 3, msxc, pea3, spry 4 and wnt7a. Primer sequences can be found in supplementary material Table S1. The Ring1b riboprobe was directed against the C-terminal $500 \mathrm{bp}$ of the cDNA.

\section{Bead implantation}

Bead implantations were carried out essentially as described by Picker et al. (Picker et al., 2009). Recombinant human FGF4 (R\&D Systems) was dissolved in PBS containing $0.1 \%$ BSA at a concentration of $250 \mu \mathrm{g} / \mathrm{ml}$. The bead solution was washed in methanol and air-dried. Beads were overnight soaked with FGF4 at $4^{\circ} \mathrm{C}$ while rotating. Dechorionated embryos were embedded into $1.5 \%$ low melting agarose. After solidification, the gel was fenestrated to expose the epidermis. The epidermis was digested away by repetitive placing of light white mineral oil drops (Sigma) on the flank of the embryo, ventral to somites 5-7. A fire-polished tungsten needle was used to open the epidermis further, in order to create a tunnel below the epidermis. FGF4-soaked beads were inserted below the epidermis and pushed anteriorly through the tunnel to the level of somite boundary 2-3.

\section{Immunohistochemistry}

Embryos were fixed in 40\% ethanol, 5\% acetic acid and 10\% formalin for 2 hours at room temperature, embedded in $1.5 \%$ low melting agarose and processed into paraffin. Primary antibody was rabbit anti-Tbx5 (1:50; 55866, Eurogentec) and secondary was biotinylated goat anti-rabbit IgG (1:800; DakoCytomation). For whole-mount immunohistochemistry, embryos were fixed overnight at $4^{\circ} \mathrm{C}$ in Dent's fixative, digested in PBS containing $10 \mu \mathrm{g} / \mathrm{ml}$ proteinase $\mathrm{K}, 0.1 \%$ Tween 20 and blocked in PBS containing $10 \%$ normal goat serum, $0.5 \%$ DMSO and $0.3 \%$ Triton $\mathrm{X}-100$. Primary antibody was rabbit anti-pH3 (1:750, sc8656R, Santa Cruz) and secondary goat anti-rabbit IgG (1:300, DakoCytomation).

\section{TUNEL}

To detect apoptotic cells, whole-mount TUNEL staining was performed using the In Situ Cell Death Detection Kit (Roche) according to the manufacturer's recommendations. 


\section{RESULTS}

\section{Generation of ring $1 \mathrm{~b}$ mutants}

To study the function of Ring $1 \mathrm{~b}$ in vertebrate development, we generated ringlb knockout zebrafish using zinc finger nuclease (ZFN)-mediated targeted gene inactivation (Meng et al., 2008). We identified potential ZFN-target sites in the coding sequence of zebrafish ringlb (BC164137.1) using ZiFit 3.0 (http://zifit.partners.org/ZiFiT/). A suitable ZFN-target site (exon 4, bp 480-503) was recovered by using the 'OPEN' strategy (Fig. 1A,B) (Maeder et al., 2008). ZFN recognizing the 9 bp that flanked the target site were generated and $100 \mathrm{pg}$ mRNA encoding each ZFN was injected into one- or two-cell stage eggs. Functionality of the ZFN was verified in vivo and injected embryos were raised to adulthood. Out of 25 potential founders, we identified two fish in which ring $1 b$ was mutated at the ZFN cleavage site (Fig. 1B). As reported for other ZFNs, the mutated alleles were of insertion/deletion origin (Doyon et al., 2008; Foley et al., 2009; Meng et al., 2008). One mutation leads to insertion of $4 \mathrm{bp}$ within the ZFN target site, whereas the second mutation causes deletion of $14 \mathrm{bp}$ ( $\Delta 14$ mutation). Both mutations result in an open reading frame-shift that leads to a premature stop codon.

We next assayed for ring $1 b$ mRNA and protein expression. Whole-mount in situ hybridization showed strong ringlb expression in the brain and pectoral fins in wild-type embryos at 72 hpf. By contrast, ringlb mRNA was not detectable in homozygous ring $1 b$ mutants (Fig. 1D, $\mathrm{D}^{\prime}$ ), suggesting that the mutant ring $1 b$ mRNA was degraded via nonsense-mediated decay. In line with these results, Ring $1 \mathrm{~b}$ protein (Fig. 1E) and monoubiquitylation of H2A (Fig. 1F) were not detected in $72 \mathrm{hpf}$ ring $1 \mathrm{~b}$ mutants. These results indicate that both mutant alleles are functional nulls and confirm that Ring $1 \mathrm{~b}$ is the sole H2A E3 ligase in the zebrafish PRC1 complex.

Because mRNA and/or protein are often maternally deposited in zebrafish, we extended the expression analysis to stages before the onset of zygotic transcription. ring $1 b$ mRNA was indeed maternally deposited (supplementary material Fig. S1B). Moreover, Ring $1 \mathrm{~b}$ protein was detected in embryos at $2.5 \mathrm{hpf}$, i.e. before onset of zygotic gene expression (supplementary material Fig. S1C). Maternal Ring $1 \mathrm{~b}$ protein persisted up to $15 \mathrm{ss}$ and was hardly, if at all, detectable in ring $1 b$ mutants at $24 \mathrm{hpf}$ (supplementary material Fig. S1D).

As the Hox genes are among the best-characterized targets of Polycomb repression (Paro, 1995; Pirrotta, 1997), we investigated axial Hox gene expression in ring $1 b$ mutants over time. This analysis showed that, up to $24 \mathrm{hpf}$, axial Hox expression is largely normal in ring $1 b$ mutants (supplementary material Fig. S2A-H). However, at later stages, there was a progressive anterior expansion of the expression domain for the Hox genes examined (supplementary material Fig. S2I-X).

Homozygous, as well as transheterozygous deletion of both alleles led to identical phenotypes, which further established that the mutations indeed disrupt Ring $1 b$. Heterozygous mutants did not display any abnormalities. Homozygous mutants were phenotypically indistinguishable from wild-type siblings up to 24 hpf. During organogenesis, however, ringlb mutants displayed several defects, including jaw malformations, pericardial edema and diminished blood circulation (supplementary material Fig. S3). ring $1 b$ mutants died at around 4-5 dpf. We were able to obtain the same developmental phenotype by injecting two independent morpholinos against ringlb (supplementary material Fig. S4). Here, we focus our analysis on the striking absence of pectoral fins in ringlb mutants (Fig. 1H).
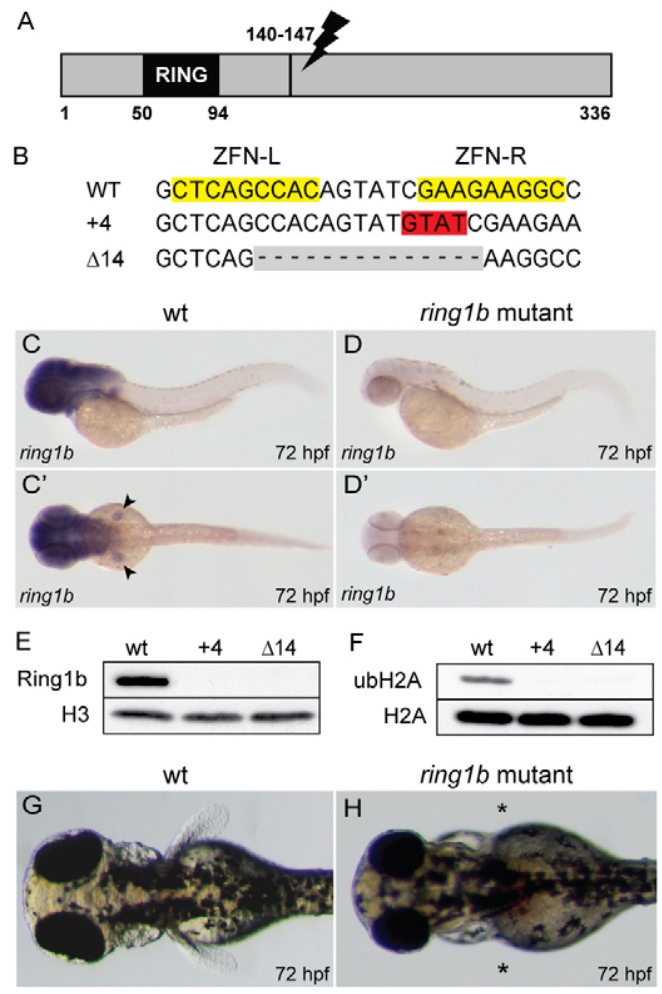

Fig. 1. Generation of ring $1 \mathbf{b}$ mutants. (A) Schematic representation of the zebrafish ring $1 \mathrm{~b}$ gene depicting the location of the ZFN target site. (B) Wild-type ring 1 b sequence is shown at the top; the ZFN target sites are highlighted in yellow. ZFN-induced bp insertions are highlighted in red, and deletions in gray. $\left(\mathbf{C}, \mathbf{C}^{\prime}\right)$ ring 1 b mRNA staining in brain and pectoral fins in wild-type larvae. (D, $\left.\mathbf{D}^{\prime}\right)$ Expression is absent in ring $1 b$ mutants. $(\mathbf{E}, \mathbf{F})$ Ring $1 \mathrm{~b}(\mathrm{E})$ and mono-ubiquitylated histone $\mathrm{H} 2 \mathrm{~A}(\mathrm{~F})$ are not detected in $72 \mathrm{hpf}$ ring $1 \mathrm{~b}$ mutants by western blot analysis. $(\mathbf{G}, \mathbf{H})$ Dorsal view of wild-type $(\mathrm{G})$ and ring $1 \mathrm{~b}(\mathrm{H})$ larvae at 72 $\mathrm{hpf}$. Asterisks indicate the lack of pectoral fins in ring $1 \mathrm{~b}$ mutants.

\section{Rescue of the ring $1 b$ phenotype by wild-type ring $1 b$ mRNA}

To validate that the observed developmental phenotype correlated with loss of Ring $1 \mathrm{~b}$, we injected wild-type myc-tagged-ring $1 b$ mRNA into one- to two-cell stage eggs derived from heterozygote ring $1 b$ crosses. We assayed injected ring $1 b$ mutants for expression of tbx 5 and hoxd $9 a$, a reported direct target of Ring $1 \mathrm{~b}$-mediated silencing (Li et al., 2011) that is also expressed in the fin bud. Injection of wild-type ring $1 b$ mRNA restricts the anterior boundary of axial hoxd $9 a$ expression in ring $1 b$ mutants, although not to the extent in wild type (Fig. 2A-E). Moreover, exogenous wild-type ring $1 b$ mRNA restored tbx 5 and hoxd $9 a$ expression in the fin bud in a dose-dependent manner and partially rescued fin bud outgrowth in ring $1 b$ homozygotes at $72 \mathrm{hpf}$ (Fig. 2L). Western blot analysis confirmed that myc-tagged Ring $1 \mathrm{~b}$ protein was expressed in a dose-dependent manner at $24 \mathrm{hpf}$ (Fig. 2M). Of note, exogenous Ring $1 \mathrm{~b}$ protein levels were greatly diminished at $48 \mathrm{hpf}$ (Fig. 2N), which likely explains the partial rescue and indicates that Ring $1 b$ activity is also required for later stages of fin bud outgrowth. These results, when taken together, confirm that we have induced null mutations in ring $1 b$ and that Ring $1 \mathrm{~b}$ is essential for pectoral fin development in zebrafish. 

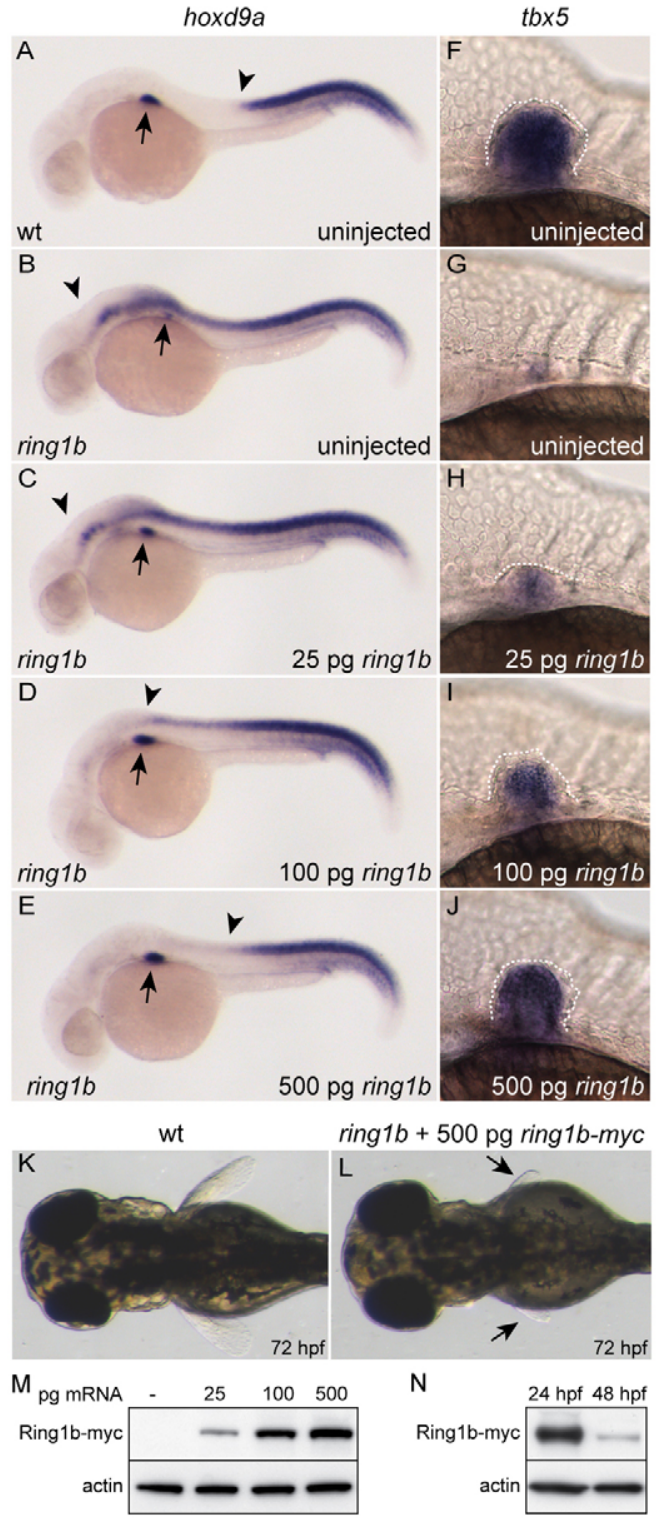

Fig. 2. Injection of ring $1 b$ mRNA rescues pectoral fin outgrowth and restores hoxd9a and tbx 5 expression in ring $1 b$ mutants. (A-J) Lateral views of $32 \mathrm{hpf}$ embryos stained for hoxd9a (A-E) and 48 hpf fin buds stained for tbx5 (F-J). Anterior expansion of axial hoxd9a expression in ring $1 b$ mutants is suppressed by exogenous wild-type ring $1 b$ mRNA in a dose-dependent manner (C-E, arrowheads). (K, L) Fin-bud hoxd9a (A-E, arrows) and tbx5 expression (F-J) is restored (arrows) in injected ring $1 \mathrm{~b}$ mutants and fin bud outgrowth is partially rescued at $72 \mathrm{hpf}$ (compare $\mathrm{K}$ with $\mathrm{L}$ ). (M) Western-blot analysis for myc-tagged Ring $1 \mathrm{~b}$ shows dose-dependent expression in $24 \mathrm{hpf}$ embryos. (N) Exogenous Ring1b protein is markedly reduced in $48 \mathrm{hpf}$ embryos.

\section{Gene expression defects in the pectoral fin mesenchyme of ring $1 \mathrm{~b}$ mutants}

To address at which point during pectoral fin development the defect arises in ring $1 b$ mutants, we assayed expression of three genes that are expressed in the fin field mesenchyme and are important for fin development. In addition to $t b x 5$, the earliest known marker for fin mesenchyme, we examined the expression of the bHLH transcription factor hand2 and of the RA-synthesizing enzyme aldh1a2 (Ahn et al., 2002; Begemann and Ingham, 2000; Begemann et al., 2001; Grandel et al., 2002; Yelon et al., 2000).

In situ hybridization experiments showed that $t b x 5$ was expressed at levels comparable to wild type in the pectoral fin field of ring $1 \mathrm{~b}$ mutants at $18 \mathrm{ss}$, albeit the expression domain appeared diffuse (Fig. 3A,B). Migration and compaction of the LPM was slightly delayed, resulting in a fuzzy $t b x 5$ expression domain in the ring $1 b$ mutants at $32 \mathrm{hpf}$. At $40 \mathrm{hpf}, t b x 5$ expression was greatly reduced in the mutant pectoral fin mesenchyme, indicating a defect in maintenance of $t b x 5$ expression. We also addressed the localization of Tbx 5 protein in the LPM of ring $1 b$ mutants, as it has been reported that the transcription factor Tbx 5 shuttles between the nucleus and cytoplasm, providing an additional layer of Tbx5 regulation (Camarata et al., 2006). Tbx5 was detectable in the ring $1 b$ pectoral fin mesenchyme, and was correctly localized in the nucleus (supplementary material Fig. S5), indicating that the regulation of Tbx 5 localization is intact.

We found that hand 2 expression was indistinguishable from wild-type siblings up to $24 \mathrm{hpf}$. However, at $32 \mathrm{hpf}$, hand 2 expression was diminished in ringlb mutants and was subsequently lost by $40 \mathrm{hpf}$ (Fig. 3R,T). In contrast to tbx5 and hand2 expression, we found that aldhla2 was already overexpressed at 18 ss and not restricted to the posterior margin of the fin field, as observed in wild-type siblings (Fig. 3U-DD).

Based on the early expression patterns of both $t b x 5$ and hand2, we conclude that specification of LPM into pectoral fin mesenchyme is initiated in ring $1 b$ mutants. However, maintenance of gene expression is impaired.

\section{Normal LPM patterning in ring1b mutants}

As aldhla 2 expression has been shown to be feedback controlled by RA during somitogenesis (Begemann et al., 2001), the altered expression of aldhla 2 in ring $1 b$ mutants at $18 \mathrm{ss}$ (18 hpf) may reflect aberrant RA signaling at even earlier stages. We addressed the possibility that the LPM is not fully specified or correctly patterned owing to deregulation of RA signaling.

To investigate LPM patterning and the response to RA signaling, we carried out double stainings at 10 ss and $15 \mathrm{ss}$, the time point at which the LPM separates into the heart and fin fields. We examined expression of the heart marker $n k x 2.5$, the LPM marker $t b x 5$ and the RA target genes $d h r s 3$ and hoxb5b, which are expressed in the pectoral fin mesenchyme (Waxman et al., 2008). This showed that the heart precursors are located correctly and express $n k x 2.5$ at normal levels at $10-15$ ss in ring $1 b$ mutants. Moreover, $t b x 5$ and hoxb5b were normally expressed at these stages, indicating that both the heart and fin fields are correctly specified in ring $1 b$ mutants (Fig. 4A-L). We noticed an upregulation of $d h r s 3$ expression in some ring $1 b$ embryos at 15 ss (Fig. 4H), which could reflect increased RA signaling or increased response to RA signaling.

To address a possible deregulation of RA signaling further, we stained for $d h r s 3$, hoxb5b and meis 3 , another RA-target gene expressed in the pectoral fin field, at 20 ss and $32 \mathrm{hpf}$ (Gongal and Waskiewicz, 2008; Kudoh et al., 2002; Manfroid et al., 2007). The expression of hoxb5, meis 3 and dhrs 3 was indistinguishable from wild-type embryos at 20 ss (Fig. $4 \mathrm{M}, \mathrm{N}, \mathrm{Q}, \mathrm{R}, \mathrm{U}, \mathrm{V})$. At $32 \mathrm{hpf}$, when a fin bud is visible in wildtype embryos, hoxb5b and meis 3 were expressed at normal levels in ring $1 b$ mutants. By contrast, expression of dhrs 3 was reproducibly upregulated in the ring $1 b$ fin field (Fig. 4P). Because of the observed upregulation of $d h s r 3$ at $32 \mathrm{hpf}$, we next 


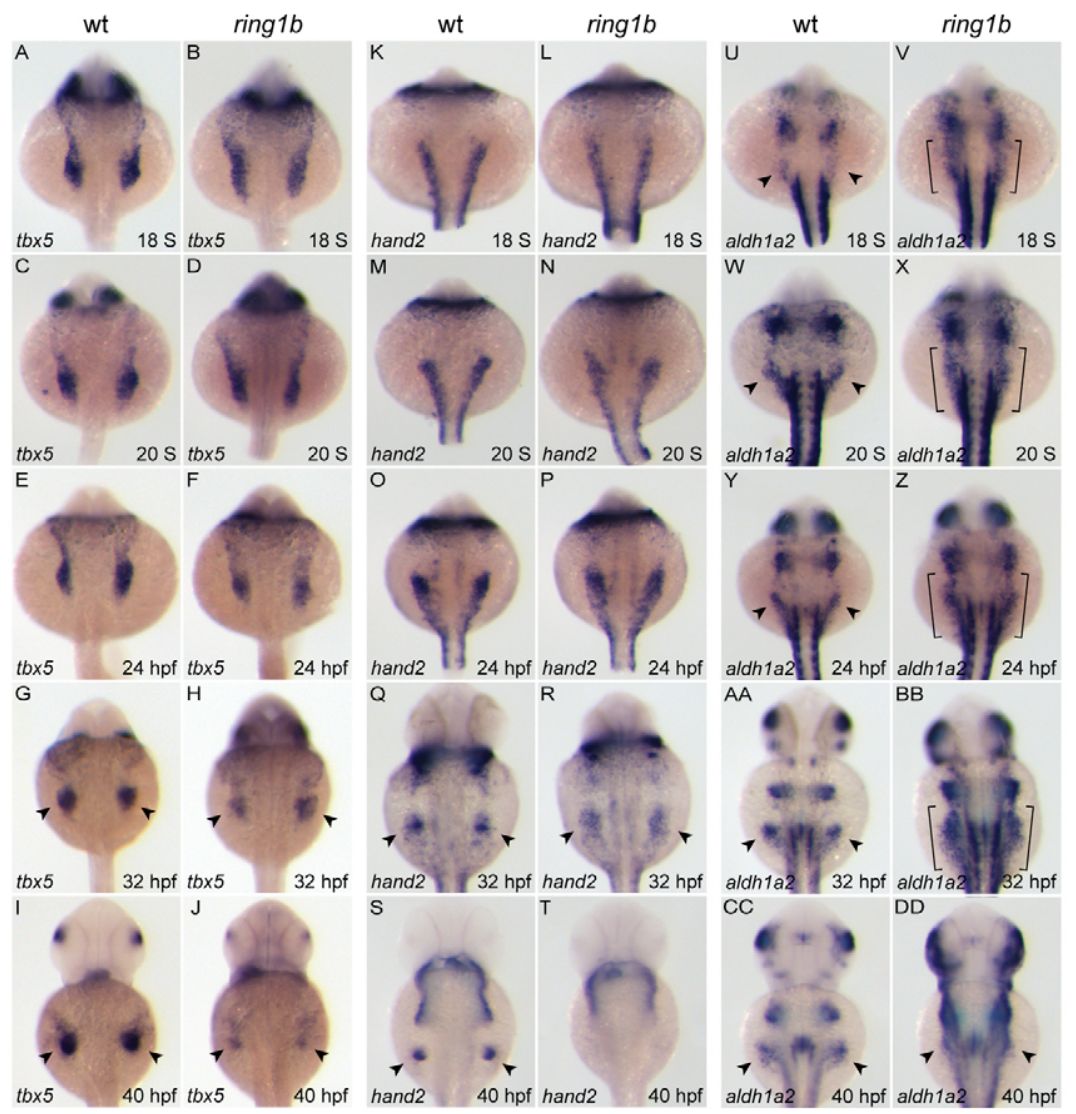

Fig. 3. Gene expression defects in the ring $1 b$ pectoral fin mesenchyme. (A-DD) Dorsal views of embryos at the indicated stages stained for $t b \times 5$ (A-J), hand2 (K-T) and aldh1a2 (U-DD). Migration and compaction of tbx5-positive pectoral fin precursors is slightly delayed in ring $1 \mathrm{~b}$ mutants $(A-F)$, whereas hand 2 expression is identical to wild-type siblings up to $24 \mathrm{hpf}(\mathrm{K}-\mathrm{P})$. Expression of tbx5 (G-J) and hand2 (Q-T) is not maintained in the ring $1 \mathrm{~b}$ fin mesenchyme. aldh1a2 is overexpressed and not restricted to the posterior LPM in ring $1 b$ mutants (U-BB, brackets). Arrowheads indicate staining at the fin bud region. examined whether timed inhibition of RA signaling could rescue aspects of the ringlb fin phenotype. RA signaling was chemically inhibited by application of DEAB at two developmental time points: 15 ss and $24 \mathrm{hpf}$. We confirmed that $10 \mu \mathrm{M}$ and $100 \mu \mathrm{M}$ DEAB efficiently inhibited RA signaling, as demonstrated by inhibition of the RA-responsive genes dhsr3 hoxc6a, hoxc8a (supplementary material Fig. S6A). DEAB treatment, when initiated at $15 \mathrm{ss}$, led to partial inhibition of fin formation in wild-type embryos accompanied by dose-dependent downregulation of gene expression (supplementary material Fig. S6B). DEAB treatment of $15 \mathrm{~s}$ ring 1 b embryos led to even weaker $t b x 5$ expression in the fin mesenchyme. DEAB treatment of wild-type embryos at $24 \mathrm{hpf}$ had little impact on fin formation, as has been reported previously (Gibert et al., 2006). By contrast, DEAB treatment of ring $1 b$ mutants at $24 \mathrm{hpf}$ led to partial restoration of gene expression. Both tbx5 and hand 2 expression levels were increased when compared with untreated mutants, albeit not reaching wild-type levels (supplementary material Fig. S6C). However, the partial rescue of mesenchymal gene expression was not sufficient to restore ectodermal $f g f 24$ expression and fin outgrowth. Overall, these data suggest that there is an increase in RA signaling or in the response to RA signaling in ring $1 b$ mutants after $24 \mathrm{hpf}$ that may contribute to the pectoral fin phenotype.

\section{Impaired Fgf-signaling in ring1b mutants}

Tbx 5 promotes expression of $f g f 24$, which, in turn, maintains $t b \times 5$ and induces $f g f 10$ in the pectoral fin mesenchyme to promote fin bud outgrowth (Fischer et al., 2003). As tbx5 expression is initiated, but not maintained, in ring $1 b$ mutants, we addressed whether processes directly downstream of $t b x 5$ were deregulated. We performed an expression time-course analysis for $f g f 24$ and fgf10. $f g f 24$ expression was initiated in both wild type and ring $1 b$ mutants at 18 ss (Fig. 5A,B). However, $f g f 24$ was expressed at lower levels and in a smaller domain in the mutants. Low levels of $f g f 24$ persisted at later developmental stages, although expression was progressively restricted to a very small domain. Expression of $f g f 10$ was also properly initiated at $20 \mathrm{ss}$ in ring $1 b$ mutants, albeit at greatly reduced levels. At later stages, $f g f 10$ expression remained markedly decreased, similar to $f g f 24$ (Fig. $5 \mathrm{~N}, \mathrm{P}$ ). We also examined expression of the Fgf receptors fgfrla, $f g f r 2$ and $f g f r 3$ in the developing fin bud (supplementary material Fig. S7). fgfrla was not expressed in either wild-type or ring $1 b$ embryos at 18 ss. At $24 \mathrm{hpf}$, fgfrla expression was reduced in ring $1 b$ mutants and expression was diminished further at $32 \mathrm{hpf}$. The mesenchymal fgf $r 2$ expression domain was slightly broader in ring $1 b$ mutants at 18 ss. However, expression was not maintained. We detected a slight expansion of the $f g f r 3$ expression domain in ring $1 b$ mutants at $18 \mathrm{ss}$. At both 24 and $32 \mathrm{hpf}, f g f r 3$ was overexpressed and the expression domain was expanded. Interestingly, a correlation between lack of Fgf8 signaling and expansion of the $f g f r 3$ expression domain has been previously reported (SleptsovaFriedrich et al., 2001). These results suggest that Fgf signaling is never fully activated in ring $1 b$ mutants.

To test this further, we examined whether activation of Fgf target genes was disrupted in the pectoral fin field of ring $1 b$ mutants. Analysis of dusp6, pea3 and spry4 (Furthauer et al., 2001; Kawakami et al., 2001; Roehl et al., 2001) showed that expression of all three genes was impaired in ring $1 b$ mutants at $24 \mathrm{hpf}$ and 32 hpf (Fig. 6). pea3 levels were severely reduced, whereas dusp6 and spry4 expression was undetectable. This confirmed that Fgf signaling, which is essential for pectoral fin mesenchyme compaction and fin bud outgrowth, is disrupted in ring $1 b$ mutants. Importantly, all examined processes downstream of Fgf signaling 

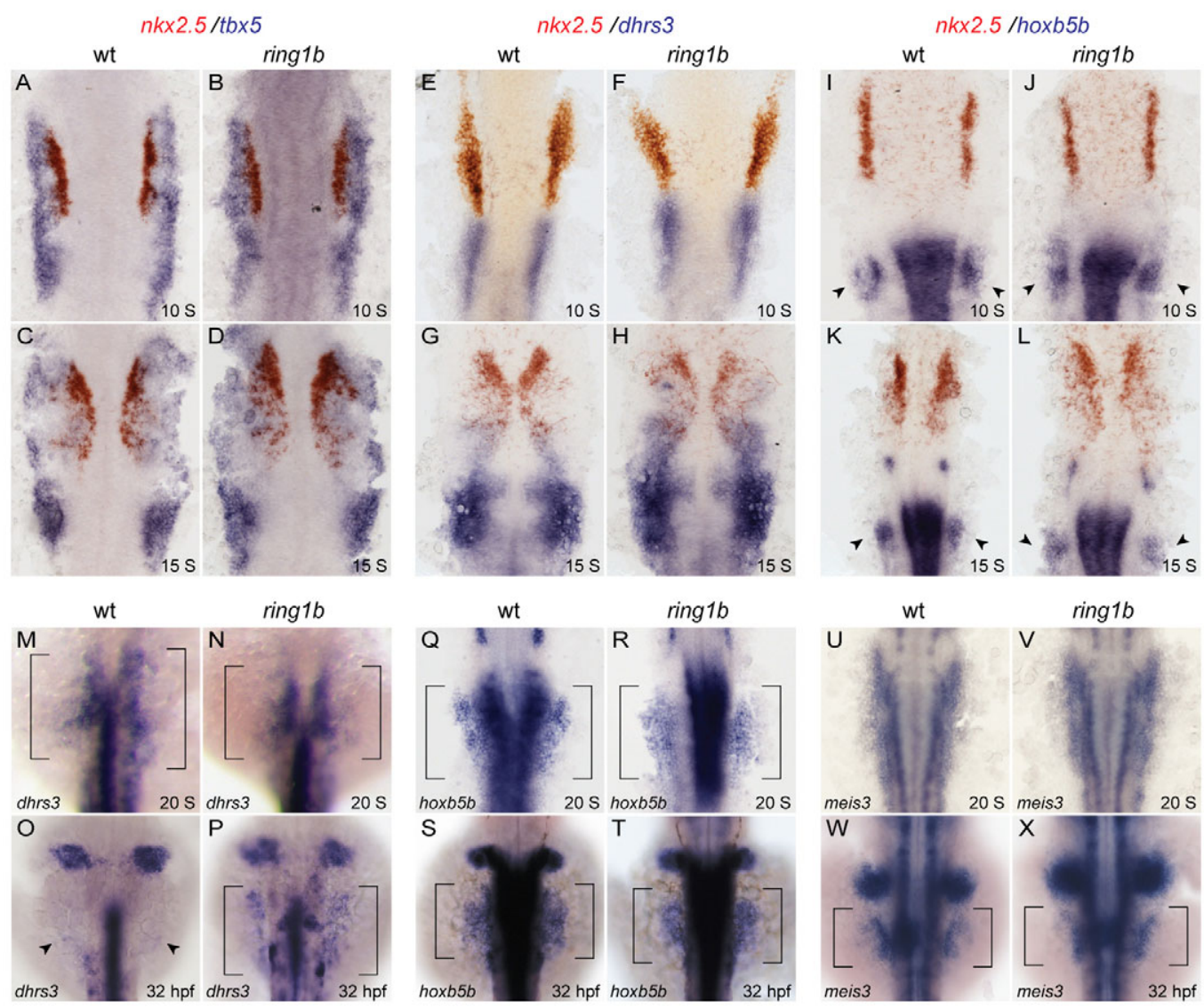

were severely impaired in ring $1 b$ mutants. This included reduced or absent expression of genes involved in anterior-posterior (AP) and dorsal-ventral (DV) patterning, as well as the absence of ectodermal gene expression (supplementary material Fig. S8). The latter finding indicated that the AER, an Fgf-dependent signaling center essential for proximal-distal outgrowth of the pectoral fin bud (Kawakami et al., 2001), was not established in ring $1 b$ mutants.

We also assayed for proliferation by $\mathrm{pH} 3$ staining and found that it was impaired only from $32 \mathrm{hpf}$ onwards (supplementary material Fig. S9A). Because Fgf signaling is greatly reduced at earlier time points, this reduction in proliferation reflects a secondary effect, which is in agreement with the previously reported role of Fgf signaling in cell-cycle progression (Prykhozhij and Neumann, 2008). Finally, only very few apoptotic cells were detected in the ring $1 b$ fin field (supplementary material Fig. S9B).

\section{Exogenous FGF restores gene expression but is not sufficient to promote fin bud outgrowth in ring 16 mutants}

It has been shown that exogenously provided FGF, by means of FGF-coated bead implantation into the flank of zebrafish embryos, can replace AER function and rescue gene expression in the pectoral fin bud (Grandel et al., 2000; Norton et al., 2005). As mesodermal Fgf signaling is impaired in ring $1 b$ mutants, we explored whether exogenously provided FGF would be sufficient to restore the positive Fgf signaling feedback loop and promote fin bud outgrowth in ring $1 b$ mutants.

To test successful loading of the beads, we first confirmed that implantation of FGF-coated beads at the 1000-cell stage promoted ectopic expression of the FGF target genes dusp6, pea 3 and spry 4 at $90 \%$ epiboly (supplementary material Fig. S10). by maintained $t b x 5$ expression.
Fig. 4. LPM patterning and the RA-signaling response in ring1b mutants. (A-L) Double in situ hybridization for $n k \times 2.5$ in red and tbx5 (A-D), dhrs3 (E$\mathrm{H})$ and hoxb5b (I-L) in blue at 10 ss and 15 ss shows similar staining patterns in wild-type and ring $1 b$ mutants.

Arrowheads indicate staining at the pectoral fin mesenchyme.

(M-X) Dorsal views of embryos stained for the RA targets dhrs3 (M-P), hoxb5b (Q-T) and meis3 $(\mathrm{U}-\mathrm{X})$ at $20 \mathrm{ss}$ and $32 \mathrm{hpf}$. Expression of hoxb5b and meis3 is normal in the ring $1 b$ LPM at 20 ss and 32 hpf, whereas dhrs 3 expression is upregulated in the ring $1 b$ LPM at $32 \mathrm{hpf}(\mathrm{P})$. Arrowheads indicate staining at the fin bud region.

We next implanted FGF4-coated beads in the flank of embryos at 15-20 ss because of the early defects in Fgf signaling in ring $1 b$ mutants. Exogenously provided FGF4 promoted maintenance of $t b x 5$ expression in the ring $1 b$ pectoral fin field (Fig. 7B). Importantly, the $t b x 5$ expression domain was increased upon bead implantation and was always directly adjacent to the FGF4-coated implanted bead. Thus, exogenously provided FGF4 enabled a domain of $t b x 5$ expression that more closely resembled that of wild-type embryos. However, $f g f 24$ and $f g f 10$ expression were not detectable in the pectoral fin field of bead-implanted ring $1 b$ embryos at $40 \mathrm{hpf}$, and fin bud outgrowth was not restored (Fig. 7D,F,H). Taken together, we conclude that the Ring1b-deficient fin precursors are partially responsive to FGF signaling, as illustrated

\section{Genetic activation of Fgf signaling stimulates fin bud outgrowth in ring $1 \mathrm{~b}$ mutants}

We postulated that a stronger or different Fgf stimulus might be required to promote fin outgrowth in ring $1 b$ mutants. To test this hypothesis, we sought to stimulate mesodermal Fgf signaling by genetic means. Zebrafish mutants with locally increased pectoral fin mesenchymal Fgf signaling have not been described to our knowledge. However, Wnt signaling has been shown to cooperate with FGF signaling during limb initiation and outgrowth in several studies in chick, mouse and zebrafish (Agarwal et al., 2003; Galceran et al., 1999; Hill et al., 2006; Kawakami et al., 2001; Nagayoshi et al., 2008; Narita et al., 2005; Ng et al., 2002; ten Berge et al., 2008). In chick, implantation of WNT2b- or $\beta$-cateninexpressing cells induces ectopic $f g f 10$ expression and limb bud outgrowth (Kawakami et al., 2001). Therefore, we hypothesized that the apc mutants that exhibit hyperactivated Wnt signaling 


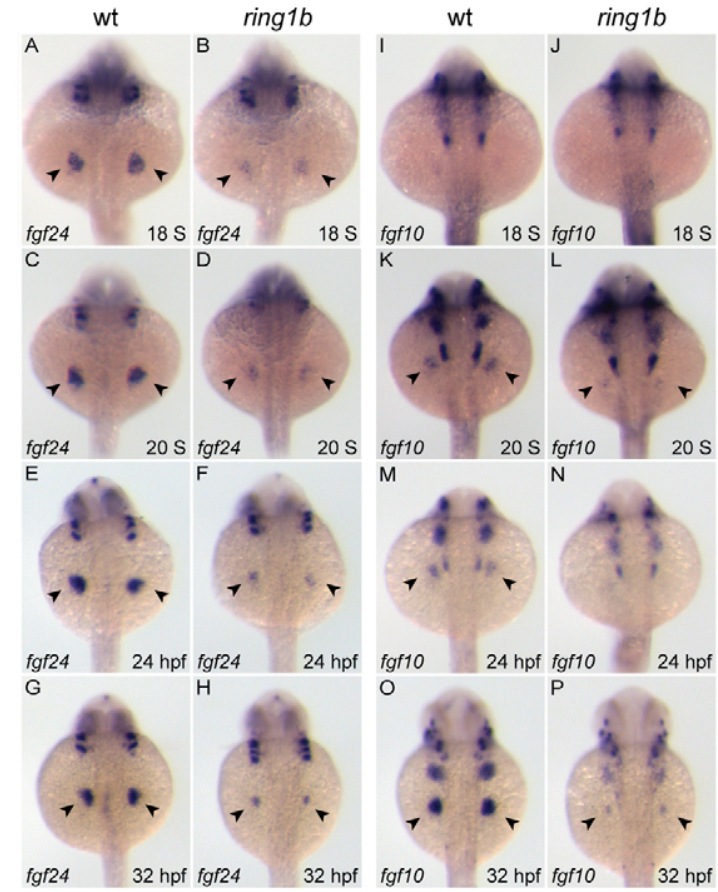

Fig. 5. Reduced fgf 24 and $f g f 10$ expression in ring $1 b$ fin mesenchyme. (A-P) Dorsal views of embryos stained for fgf $24(\mathrm{~A}-\mathrm{H})$ and fgf10 (I-P). Expression of both genes is initiated at the correct developmental stage, but the levels are reduced in the ring $1 \mathrm{~b}$ pectoral fin mesenchyme. fgf 24 and $f g f 10$ expression is restricted to a very small domain in the ring $1 \mathrm{~b}$ fin mesenchyme at $32 \mathrm{hpf}(\mathrm{H}, \mathrm{P})$. Arrowheads indicate staining at the pectoral fin mesenchyme and fin bud region.

would provide a good candidate for increased Fgf signaling. In apc mutants, canonical Wnt signaling is hyperactivated owing to destabilization of the axin-containing degradation complex, of which Apc is an essential component (Clevers, 2006; Fodde et al., 2001; Hurlstone et al., 2003). Consequently, $\beta$-catenin is stabilized, accumulates in the nucleus and, together with TCF, activates Wnttarget gene transcription (Korinek et al., 1997). Indeed, the Wnttarget genes myca (c-myc) and axin2 (He et al., 1998; Jho et al., 2002) were overexpressed in the $a p c$ pectoral fin mesenchyme (supplementary material Fig. S11B,F). myca and axin2 were downregulated in the ring $1 b$ fin field at $56 \mathrm{hpf}$ (supplementary material Fig. S11C,G); however, this probably represents a secondary effect resulting from disruption of the pectoral fin program.
To determine whether mesodermal Fgf-signaling was increased in apc mutants, we assayed expression of $t b \times 5, f g f 24$ and $f g f 10$ at $32 \mathrm{hpf}$ and $72 \mathrm{hpf}$. Indeed, all three genes were upregulated and the expression domains were expanded in apc fin buds at $32 \mathrm{hpf}$; this was exacerbated at $72 \mathrm{hpf}$ (Fig. 8B,F,J,N,R,V). At $72 \mathrm{hpf}$, fin elongation was impaired in $a p c$ mutants, despite a large $t b x 5$ expression domain. The pectoral fin ectoderm displayed a ruffled morphology and $f g f 24$ and $f g f 10$ were expressed at high levels in the mesenchyme (Fig. 8R,V,Z). Furthermore, expression of the Fgf target genes dusp6, spry and pea3 was highly increased in apc mutants (supplementary material Fig. S12). These data showed that apc mutants exhibit increased activation of the $t b x 5-f g f 24-f g f 10$ signaling cascade, although $f g f 24$ expression remains confined to the mesenchyme and is not expressed in the ectoderm.

To test whether this level of activation could rescue the pectoral fin developmental program, we generated apc/ring $1 b$ mutants. As expected, we found that fin outgrowth is initiated in the apc/ring $1 b$ animals, as a small fin bud visible at $40 \mathrm{hpf}$, continued to grow and gave rise to a small, albeit misshapen, fin at $72 \mathrm{hpf}$ (Fig. 8BB). We analyzed expression of the $t b x 5-f g f 24-f g f 10$ axis in the apc/ring $1 b$ fin buds at different stages of development. At $32 \mathrm{hpf}$, tbx5 expression in apc/ring $1 b$ mutants is similar to that of ring $1 b$ mutants: compaction of pectoral fin mesenchyme occurs, but $t b \times 5$ is poorly expressed and the domain is not well demarcated. Expression of $f g f 24$ and $f g f 10$, although increased in apc/ring $1 b$ embryos when compared with ring $1 b$ mutants, did not reach wildtype levels. Interestingly, $t b x 5$ expression is well maintained in apc/ring 1 butants at $72 \mathrm{hpf}$ (Fig. 8P). This is in striking contrast to ring $1 b$ mutants, in which $t b x 5$ expression was not detectable at this stage. Expression of both $f g f 24$ and $f g f 10$ in $72 \mathrm{hpf}$ apc/ring $1 \mathrm{~b}$ fins resembles that of apc mutants, but the expression domains are smaller (Fig. 8T,X). Similarly, Fgf-target genes are expressed in apc/ring $1 b$ mutants, but not in ring $1 b$ mutants (supplementary material Fig. S12). Taken together, genetic activation of Fgfsignaling restores the pectoral fin program of Ringlb-deficient embryos and is sufficient to promote fin bud outgrowth.

\section{DISCUSSION}

In this study, we implemented ZFN-mediated targeted gene inactivation to generate the first zebrafish mutant in a PcG gene. We show that, in contrast to mice, ring $1 b$ homozygote zebrafish mutants are embryonically viable and exhibit developmental defects that enable the study of Ringlb in vertebrate development. One striking feature of the ring $1 b$ phenotype is the lack of pectoral fins, whereas the lateral plate mesoderm (LPM) is specified appropriately and the fin program initiates correctly with the expression of $t b x 5$. In the absence of Ring $1 \mathrm{~b}$, upregulation of RA
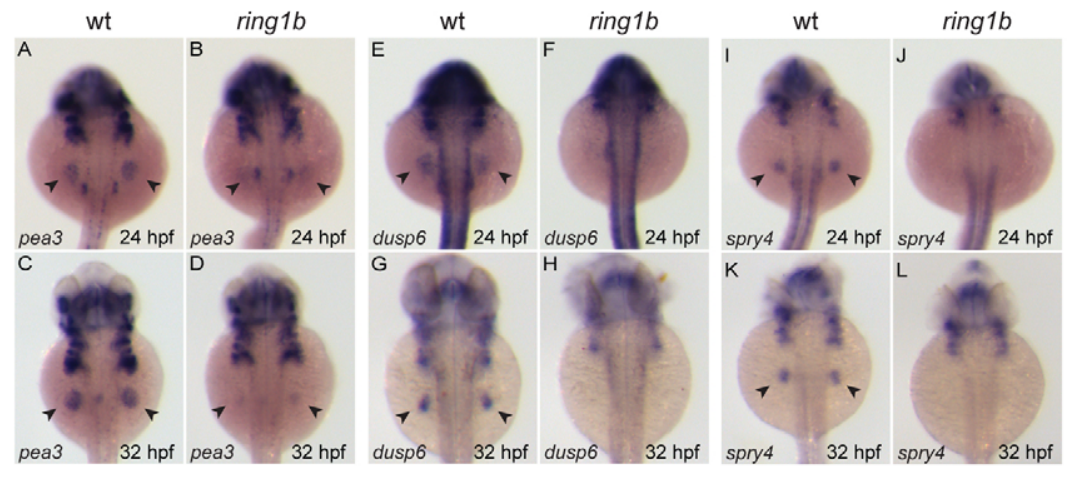

Fig. 6. Loss of Fgf target gene expression in ring $\mathbf{1 b}$ mutants. (A-L) Expression analysis of the Fgf target genes pea3 (A-D), dusp6 (E-H) and spry4 (I-L) at $24 \mathrm{hpf}$ and $32 \mathrm{hpf}$. pea3 is greatly reduced and dusp6 and spry4 are undetectable in the ring $1 b$ pectoral fin mesenchyme. Arrowheads indicate staining at the fin bud region. 


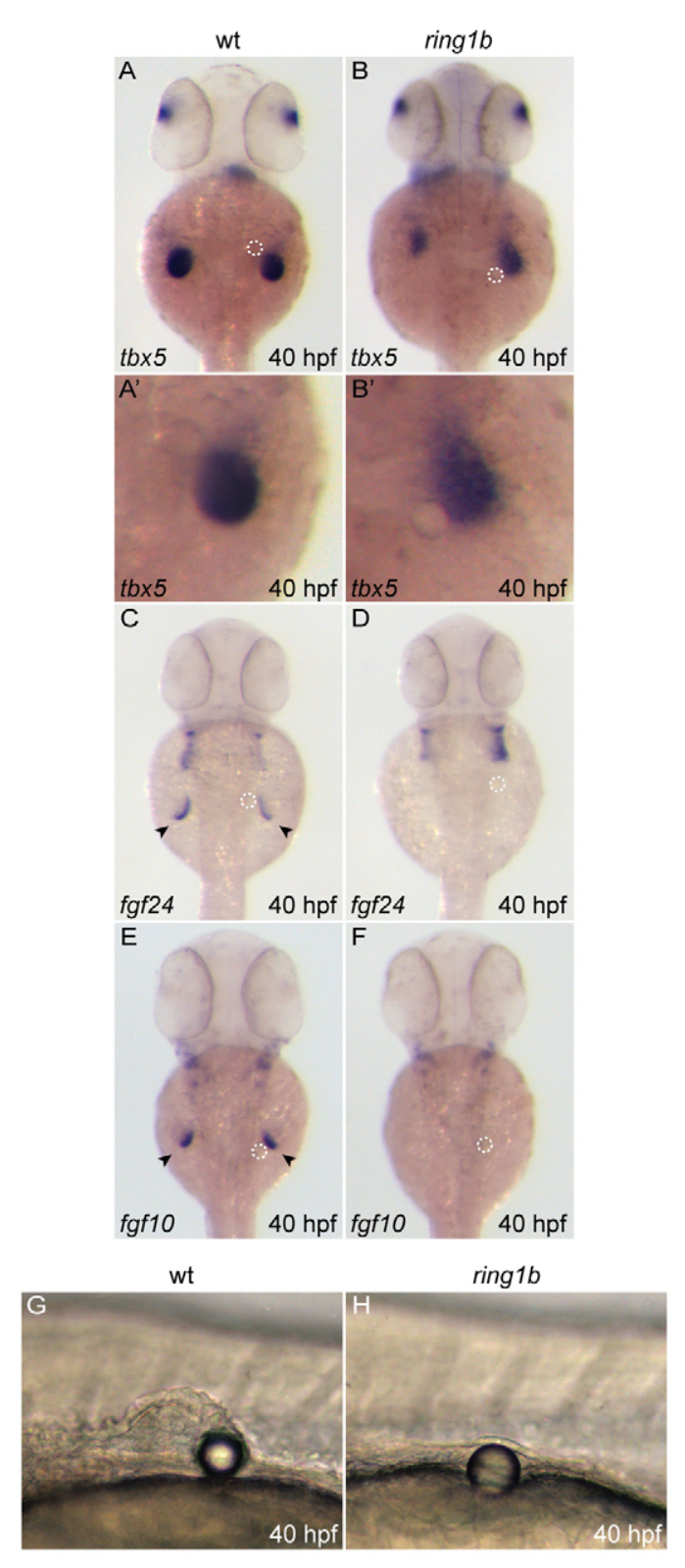

Fig. 7. FGF4-soaked bead implantation restores $t b \times 5$ expression but not fin bud outgrowth. (A-F) Dorsal views of bead-implanted embryos stained for tbx5 (A-B'), fgf24 (C,D) and fgf10 (E,F) at $40 \mathrm{hpf}$. $(\mathbf{G}, \mathbf{H})$ Exogenous FGF4 enhances tbx5 expression maintenance but is not sufficient to initiate fgf 24 or fgf10 expression in ring $1 \mathrm{~b}$ mutants. Bead location is indicated by the white dashed circle. Pectoral fin bud outgrowth is not restored in ring $1 \mathrm{~b}$ mutants. Arrowheads indicate staining at the fin bud region.

signaling occurs and Fgf signaling is not sufficiently activated in the pectoral fin mesenchyme, culminating to loss of fin bud outgrowth.

\section{Hox genes in pectoral fin development}

We observed that axial Hox gene expression is only mildly affected until $24 \mathrm{hpf}$ in ring $1 \mathrm{~b}$ mutants, indicating that initiation of axis specification is largely correct. ring $1 b$ mRNA and protein are maternally deposited, which could explain the relatively late onset of Hox gene deregulation in ring $1 b$ mutants.
Correct axial Hox gene expression is also essential for proper induction and positioning of the forelimb along the axis in vertebrates (Burke et al., 1995; Cohn et al., 1997). In zebrafish, it has been shown that regulation of axial Hox gene function by $p b x 4$ is essential for the establishment of the pectoral fin field (Popperl et al., 2000). Pxb4 deficiency in the lazarus mutant results in a distinct lack of $t b x 5$ expression at $24 \mathrm{hpf}$ and suggests that the LPM is never specified as pectoral fin mesenchyme (Popperl et al., 2000). By contrast, in ring $1 b$ mutants, $t b x 5$ expression in the LPM at $24 \mathrm{hpf}$ is fairly normal, which strengthens the conclusion that Hox-mediated induction of the forelimb field is unaffected.

Interestingly, the forelimb field is positioned just anteriorly of axial hoxc6 and hoxc8 expression (Bejder and Hall, 2002). It has been demonstrated that anterior extension of hoxc6 and hoxc 8 expression in pythons correlates with lack of forelimbs (Cohn and Tickle, 1999). In ring $1 b$ mutants, anterior expansion of the hoxc6 and hoxc 8 expression domains occurs only after the fin field has been established, at $24 \mathrm{hpf}$. Indeed, several pectoral fin markers, including $t b x 5$, hoxb5b and meis 3 were expressed at the proper location along the AP axis in ring $1 b$ mutants. Thus, axial Hox gene function is sufficient to mediate correct specification and positioning of the pectoral fin field in ring $1 b$ mutants.

\section{RA signaling in ring $1 b$ embryos}

Aldh1a2 is the only gene from the genes involved in pectoral fin development we examined that is robustly overexpressed in the ring $1 b$ LPM. This enzyme catalyzes the last step in RA synthesis (Begemann et al., 2001; Grandel et al., 2002). Axial aldh1a2 expression is essential for $t b x 5$ expression and initiation of the pectoral fin field, whereas aldhla2 expression in the LPM is less crucial, as chemical inhibition of RA signaling after 16-22 hpf does not abrogate pectoral fin emergence (Gibert et al., 2006). Despite the high aldh1a2 expression levels, we did not detect general upregulation of RA target genes in the LPM of ring $1 b$ mutants. However, the RA-target gene dhrs 3 was reproducibly upregulated in ring $1 \mathrm{~b}$ mutants at $32 \mathrm{hpf}$ and potent inhibition of RA signaling from $24 \mathrm{hpf}$ onwards led to partial restoration of mesenchymal gene expression. It is plausible that increased RA signaling after $24 \mathrm{hpf}$ contributes to the developmental defect of fin formation in ring $1 b$ mutants. However, fin outgrowth is not initiated upon inhibition of RA signaling at $24 \mathrm{hpf}$, and inhibition at $15 \mathrm{ss}$ in fact enhances the defect in fin mesenchyme compaction. Thus, our data indicate that deregulation of RA signaling may contribute to, but is not primarily involved in, the ring $1 b$ fin phenotype.

\section{The interplay of Wnt and Fgf-signaling in pectoral fin development}

Pectoral fin development is partially rescued in apc/ring $1 b$ mutants through potentiation of the $t b x 5-f g f 24-f g f 10$ axis, most probably owing to increased activation of Wnt signaling. In support of this, the Wnt target genes myca and axin2 are overexpressed in the apc fin mesoderm, indicating an increased Wnt-signaling response. We postulate that this augmented Wntsignaling response in the mesoderm stimulates, directly or indirectly, $t b x 5, f g f 24$ and $f g f 10$ expression. Interestingly, in $a p c$ mutants, $f g f 24$ and $f g f 10$ are overexpressed in other tissues besides the pectoral fin, including the pharyngeal arches. The overexpression in the pharyngeal arches is Tbx5 independent, as $t b \times 5$ is not expressed there. We postulate that the increased $t b \times 5$ expression in the apc fin buds is attributed to the increased Fgf signaling, as tbx5 expression is feedback controlled by Fgf 

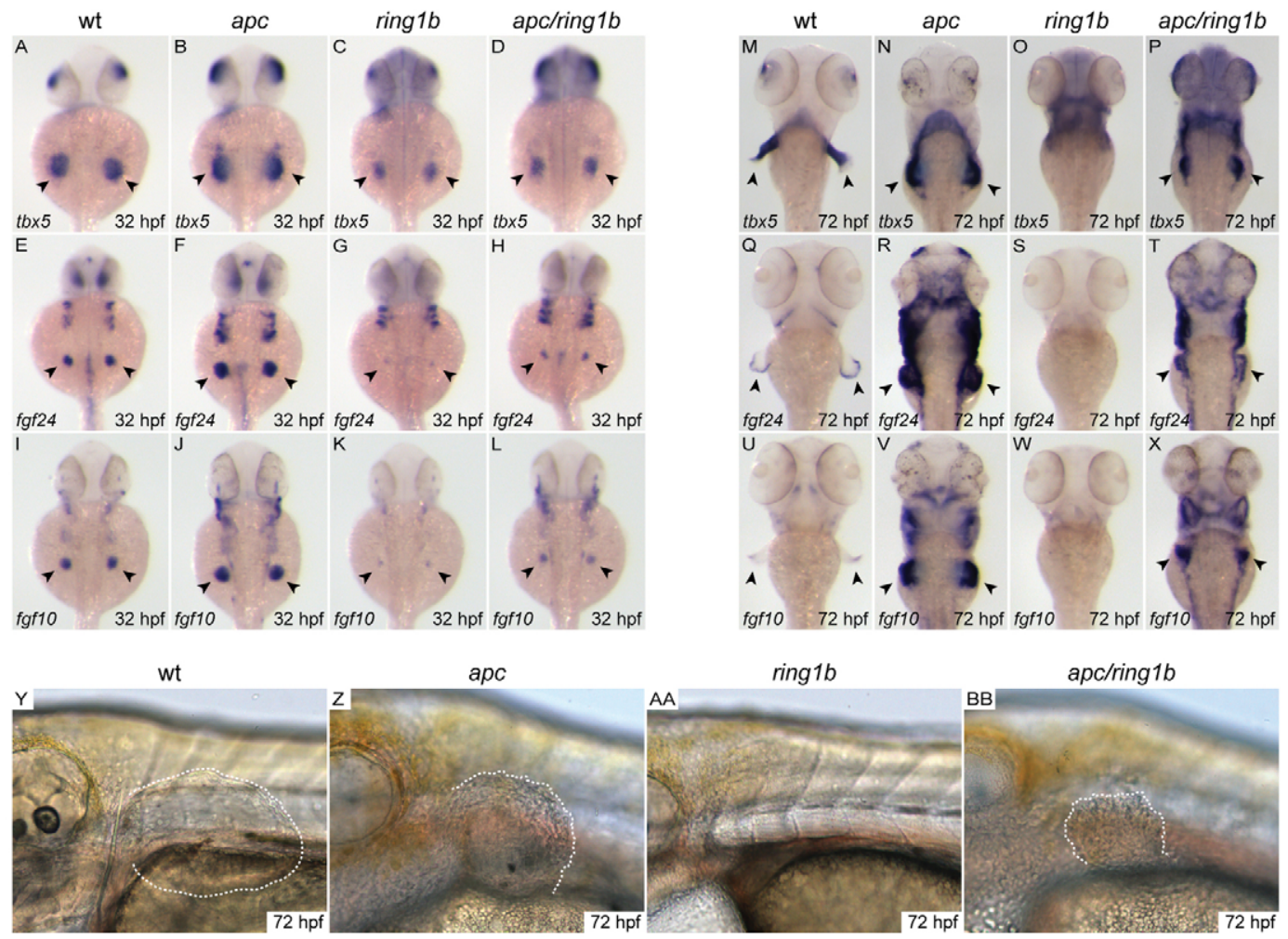

Fig. 8. Restoration of mesenchymal gene expression and fin bud outgrowth in apc/ring1 $\mathbf{b}$ mutants. (A-X) Dorsal views of embryos of the indicated genotypes stained for tbx5, fgf24 and fgf10 at $32 \mathrm{hpf}(\mathrm{A}-\mathrm{L})$ and $72 \mathrm{hpf}(\mathrm{M}-\mathrm{X})$. tbx5 (B,N), fgf24 (F,R) and fgf10 (J,V) are overexpressed in the apc pectoral fin mesenchyme at both 32 and $72 \mathrm{hpf}$. Expression of $f g f 24(\mathrm{H})$ and $f g f 10(\mathrm{~L})$ is increased in apc/ring $1 \mathrm{~b}$ mutants compared with ring $1 \mathrm{~b}$ mutants $(\mathrm{G}, \mathrm{K})$ at $32 \mathrm{hpf}$. Expression of tbx5 (P), fgf24 $(\mathrm{T})$ and $f g f 10(\mathrm{X})$ is maintained in apc/ring $1 \mathrm{~b}$ mutants at $72 \mathrm{hpf}$. Arrowheads indicate staining at the fin bud region. (Y-BB) Lateral views of $72 \mathrm{hpf}$ embryos of the indicated genotypes at the level of the pectoral fin. A rudimentary fin bud (outlined) is formed in apc/ring $1 \mathrm{~b}$ mutants at $72 \mathrm{hpf}$ (BB).

signaling. This raises the possibility that the overexpression of $f g f 24$ and $f g f 10$ in both pharyngeal arches and pectoral fin mesenchyme of apc mutants is caused by a common mechanism, which is then Tbx5 independent.

Importantly, mesodermal $f g f 24$ expression is downregulated at $30 \mathrm{hpf}$ (Fischer et al., 2003) as ectodermal $f g f 24$ commences. This 'switch' does not occur in $a p c$ and apc/ring $1 b$ mutants, and, instead, high amounts of $f g f 24$ remain mesodermal. Ectodermal Fgf signaling is required for elongation of the growing fin bud. Therefore, the deregulation in $f g f 24$ distribution may account for the presence of small fins with ruffled morphology in $a p c$ and apc/ringlb mutants.

\section{Epigenetic regulation of pectoral fin development}

We have shown that pectoral fin development is disrupted due to loss of Ring $1 \mathrm{~b}$ and that impaired Fgf-signaling is causally linked to this phenotype. Although we cannot exclude the possibility that Ring $1 b$ directly represses a single negative regulator of Fgf signaling, we propose that Ringlb deficiency causes a broader deregulation of gene expression based on several observations.

Zebrafish mutants that are deficient for globally acting chromatin-associated proteins show surprising tissue-specific defects, such as loss of pectoral fins. These mutants include the lazarus/pbx4 (Popperl et al., 2000), colgate/histone deacetylase 1 (HDAC1) (Nambiar et al., 2007) and mediator component thyroid hormone receptor-associated protein (TRAP)230/MED12 (Hong et al., 2005; Rau et al., 2006).
Mechanistically, the lack of fins in ringlb mutants could possibly be ascribed to tissue-specific interactions between the PRC1 repressive pathway and single master regulators of tissue development, as previously shown in some instances (Yu et al., 2012). Alternatively, the genetic disruption of an essential epigenetic pathway may have a broader impact, resulting in profound alterations of temporal and spatial controls of zebrafish fin development. For example, it is conceivable that loss of Ring1b alters the chromatin landscape and may allow the redistribution of activators and/or silencers at the expense of their normal targets. Thus, the consequences of Ring $1 \mathrm{~b}$ loss may involve activation and silencing of gene expression through altering the chromatin landscape, in addition to de-repression of direct targets.

Indeed, loss of Ringlb may not be seen as an activation switch for single genes in isolation. Ringlb inactivation in mouse embryonic stem cells causes aberrant activation of several key developmental genes and deregulation of signaling pathways involved in cellular differentiation (Leeb and Wutz, 2007; van der Stoop et al., 2008). Furthermore, PRC1 ablation lowers the threshold for cellular response to hormones during mammary development (Pietersen et al., 2008), highlighting the role of noncell autonomous effects in determining the Polycomb phenotype.

In line with this complex scenario of Ring $1 b$ function, we found that fin-specific expression of hoxa9b, hoxc $8 a$ and hoxd $9 a$, reported direct targets of $\mathrm{PcG} /$ Ring $1 \mathrm{~b}$-mediated repression, was impaired in ring $1 b$ mutants, whereas their axial expression domains were expanded. This illustrates that Ring1b loss can lead to distinct 
aberrations in gene expression, in a context-dependent fashion, and highlights the importance of PcG in the coordinated control of gene expression during development. Future work will aim to elucidate the exact mechanisms of the role of PcG epigenetic gene regulation on the limb developmental program.

\section{Acknowledgements}

We are indebted to Heiner Grandel (Technische Universitaet Dresden, Germany) for instrumental advice regarding the bead implantations. We thank Gerrit Begemann (University of Konstanz, Germany), Kenneth Poss (Duke University Medical Center, USA), William Norton (Institute Neurobiology, Gifsur-Yvette, France), Jeroen Bakkers and Stefan Schulte-Merker (Hubrecht Institute, The Netherlands) for probes, and Martin Dyers (University of Leicester, UK) for the Ring1b antibody. We are grateful to Dana Carroll (University of Utah, USA) for the vectors used to construct the ZFNs. We thank Fred van Leeuwen, Anke Sparmann and Gaetano Gargiulo (NKI) for critical reading of the manuscript and discussions.

\section{Funding}

This work was supported by the Netherlands Organization for Scientific Research [(NWO-ZonMW)-Vidi 91756322] to A.-P.G.H.

\section{Competing interests statement}

The authors declare no competing financial interests.

\section{Supplementary material}

Supplementary material available online at

http://dev.biologists.org/lookup/suppl/doi:10.1242/dev.077156/-/DC1

\section{References}

Agarwal, P., Wylie, J. N., Galceran, J., Arkhitko, O., Li, C., Deng, C., Grosschedl, R. and Bruneau, B. G. (2003). Tbx5 is essential for forelimb bud initiation following patterning of the limb field in the mouse embryo. Development 130, 623-633.

Ahn, D. G., Kourakis, M. J., Rohde, L. A., Silver, L. M. and Ho, R. K. (2002). Tbox gene tbx 5 is essential for formation of the pectoral limb bud. Nature $\mathbf{4 1 7}$, 754-758.

Begemann, G. and Ingham, P. W. (2000). Developmental regulation of Tbx5 in zebrafish embryogenesis. Mech. Dev. 90, 299-304.

Begemann, G., Schilling, T. F., Rauch, G. J., Geisler, R. and Ingham, P. W. (2001). The zebrafish neckless mutation reveals a requirement for raldh2 in mesodermal signals that pattern the hindbrain. Development 128, 3081-3094.

Bejder, L. and Hall, B. K. (2002). Limbs in whales and limblessness in other vertebrates: mechanisms of evolutionary and developmental transformation and loss. Evol. Dev. 4, 445-458.

Bracken, A. P. and Helin, K. (2009). Polycomb group proteins: navigators of lineage pathways led astray in cancer. Nat. Rev. Cancer 9, 773-784.

Burke, A. C., Nelson, C. E., Morgan, B. A. and Tabin, C. (1995). Hox genes and the evolution of vertebrate axial morphology. Development 121, 333-346.

Camarata, T., Bimber, B., Kulisz, A., Chew, T. L., Yeung, J. and Simon, H. G. (2006). LMP4 regulates Tbx5 protein subcellular localization and activity. J. Cell Biol. 174, 339-348

Camarata, T., Krcmery, J., Snyder, D., Park, S., Topczewski, J. and Simon, H. G. (2010). Pdlim7 (LMP4) regulation of Tbx5 specifies zebrafish heart atrioventricular boundary and valve formation. Dev. Biol. 337, 233-245.

Cao, R., Wang, L., Wang, H., Xia, L., Erdjument-Bromage, H., Tempst, P., Jones, R. S. and Zhang, Y. (2002). Role of histone H3 lysine 27 methylation in Polycomb-group silencing. Science 298, 1039-1043.

Carroll, D., Morton, J. J., Beumer, K. J. and Segal, D. J. (2006). Design, construction and in vitro testing of zinc finger nucleases. Nat. Protoc. 1, 13291341.

Clevers, H. (2006). Wnt/beta-catenin signaling in development and disease. Cell 127, 469-480.

Cohn, M. J. and Tickle, C. (1999). Developmental basis of limblessness and axial patterning in snakes. Nature 399, 474-479.

Cohn, M. J., Patel, K., Krumlauf, R., Wilkinson, D. G., Clarke, J. D. and Tickle, C. (1997). Hox9 genes and vertebrate limb specification. Nature 387, 97-101.

Czermin, B., Melfi, R., McCabe, D., Seitz, V., Imhof, A. and Pirrotta, V. (2002). Drosophila enhancer of Zeste/ESC complexes have a histone $\mathrm{H} 3$ methyltransferase activity that marks chromosomal Polycomb sites. Cell 111, 185-196.

de Napoles, M., Mermoud, J. E., Wakao, R., Tang, Y. A., Endoh, M., Appanah, R., Nesterova, T. B., Silva, J., Otte, A. P., Vidal, M. et al. (2004). Polycomb group proteins Ring1A/B link ubiquitylation of histone $\mathrm{H} 2 \mathrm{~A}$ to heritable gene silencing and X inactivation. Dev. Cell 7, 663-676.

Doyon, Y., McCammon, J. M., Miller, J. C., Faraji, F., Ngo, C., Katibah, G. E., Amora, R., Hocking, T. D., Zhang, L., Rebar, E. J. et al. (2008). Heritable targeted gene disruption in zebrafish using designed zinc-finger nucleases. Nat. Biotechnol. 26, 702-708.

Eskeland, R., Leeb, M., Grimes, G. R., Kress, C., Boyle, S., Sproul, D., Gilbert, N., Fan, Y., Skoultchi, A. I., Wutz, A. et al. (2010). Ring1B compacts chromatin structure and represses gene expression independent of histone ubiquitination. Mol. Cell 38, 452-464.

Fischer, S., Draper, B. W. and Neumann, C. J. (2003). The zebrafish fgf24 mutant identifies an additional level of $\mathrm{Fg}$ signaling involved in vertebrate forelimb initiation. Development 130, 3515-3524

Fodde, R., Smits, R. and Clevers, H. (2001). APC, signal transduction and genetic instability in colorectal cancer. Nat. Rev. Cancer 1, 55-67.

Foley, J. E., Yeh, J. R., Maeder, M. L., Reyon, D., Sander, J. D., Peterson, R. T. and Joung, J. K. (2009). Rapid mutation of endogenous zebrafish genes using zinc finger nucleases made by Oligomerized Pool ENgineering (OPEN). PLOS ONE 4, e4348.

Furthauer, M., Reifers, F., Brand, M., Thisse, B. and Thisse, C. (2001). sprouty4 acts in vivo as a feedback-induced antagonist of FGF signaling in zebrafish. Development, 128, 2175-2186.

Galceran, J., Farinas, I., Depew, M. J., Clevers, H. and Grosschedl, R. (1999). Wnt3a-/-like phenotype and limb deficiency in Lef1(-I-)Tcf1(-/-) mice. Genes Dev. 13, 709-717.

Gao, Z., Zhang, J., Bonasio, R., Strino, F., Sawai, A., Parisi, F., Kluger, Y. and Reinberg, D. (2012). PCGF homologs, CBX proteins, and RYBP define functionally distinct PRC1 family complexes. Mol. Cell. 45, 344-356.

Gibert, Y., Gajewski, A., Meyer, A. and Begemann, G. (2006). Induction and prepatterning of the zebrafish pectoral fin bud requires axial retinoic acid signaling. Development 133, 2649-2659.

Gieni, R. S. and Hendzel, M. J. (2009). Polycomb group protein gene silencing, non-coding RNA, stem cells, and cancer. Biochem. Cell Biol. 87, 711-746.

Gongal, P. A. and Waskiewicz, A. J. (2008). Zebrafish model of

holoprosencephaly demonstrates a key role for TGIF in regulating retinoic acid metabolism. Hum. Mol. Genet. 17, 525-538.

Grandel, H., Draper, B. W. and Schulte-Merker, S. (2000). dackel acts in the ectoderm of the zebrafish pectoral fin bud to maintain AER signaling. Development 127, 4169-4178.

Grandel, H., Lun, K., Rauch, G. J., Rhinn, M., Piotrowski, T., Houart, C., Sordino, P., Kuchler, A. M., Schulte-Merker, S., Geisler, R. et al. (2002). Retinoic acid signalling in the zebrafish embryo is necessary during presegmentation stages to pattern the anterior-posterior axis of the CNS and to induce a pectoral fin bud. Development 129, 2851-2865.

Haramis, A. P., Hurlstone, A., van der Velden, Y., Begthel, H., van den Born, M., Offerhaus, G. J. and Clevers, H. C. (2006). Adenomatous polyposis colideficient zebrafish are susceptible to digestive tract neoplasia. EMBO Rep. 7, 444-449.

Harvey, S. A. and Logan, M. P. (2006). sall4 acts downstream of tbx5 and is required for pectoral fin outgrowth. Development 133, 1165-1173.

He, T. C., Sparks, A. B., Rago, C., Hermeking, H., Zawel, L., da Costa, L. T., Morin, P. J., Vogelstein, B. and Kinzler, K. W. (1998). Identification of C-MYC as a target of the APC pathway. Science 281, 1509-1512.

Hill, T. P., Taketo, M. M., Birchmeier, W. and Hartmann, C. (2006). Multiple roles of mesenchymal beta-catenin during murine limb patterning. Development 133, 1219-1229.

Hong, S. K., Haldin, C. E., Lawson, N. D., Weinstein, B. M., Dawid, I. B. and Hukriede, N. A. (2005). The zebrafish kohtalo/trap230 gene is required for the development of the brain, neural crest, and pronephric kidney. Proc. Natl. Acad. Sci. USA 102, 18473-18478.

Hurlstone, A. F., Haramis, A. P., Wienholds, E., Begthel, H., Korving, J., Van Eeden, F., Cuppen, E., Zivkovic, D., Plasterk, R. H. and Clevers, H. (2003). The Wnt/beta-catenin pathway regulates cardiac valve formation. Nature $\mathbf{4 2 5}$ 633-637.

Jho, E. H., Zhang, T., Domon, C., Joo, C. K., Freund, J. N. and Costantini, F. (2002). Wnt/beta-catenin/Tcf signaling induces the transcription of Axin2, a negative regulator of the signaling pathway. Mol. Cell. Biol. 22, 1172-1183.

Kawakami, Y., Capdevila, J., Buscher, D., Itoh, T., Rodriguez Esteban, C. and Izpisua Belmonte, J. C. (2001). WNT signals control FGF-dependent limb initiation and AER induction in the chick embryo. Cell 104, 891-900.

Kimmel, C. B., Ballard, W. W., Kimmel, S. R., Ullmann, B. and Schilling, T. F. (1995). Stages of embryonic development of the zebrafish. Dev. Dyn. 203, 253310.

Korinek, V., Barker, N., Morin, P. J., van Wichen, D., de Weger, R., Kinzler, K. W., Vogelstein, B. and Clevers, H. (1997). Constitutive transcriptional activation by a beta-catenin-Tcf complex in APC-/- colon carcinoma. Science 275, 1784-1787

Krauss, S., Concordet, J. P. and Ingham, P. W. (1993). A functionally conserved homolog of the Drosophila segment polarity gene hh is expressed in tissues with polarizing activity in zebrafish embryos. Cell 75, 1431-1444.

Kudoh, T., Wilson, S. W. and Dawid, I. B. (2002). Distinct roles for Fgf, Wnt and retinoic acid in posteriorizing the neural ectoderm. Development 129, 43354346 
Kuzmichev, A., Nishioka, K., Erdjument-Bromage, H., Tempst, P. and Reinberg, D. (2002). Histone methyltransferase activity associated with a human multiprotein complex containing the Enhancer of Zeste protein. Genes Dev. 16, 2893-2905.

Le Faou, P., Volkel, P. and Angrand, P. O. (2011). The zebrafish genes encoding the Polycomb repressive complex (PRC) 1. Gene 475, 10-21.

Leeb, M. and Wutz, A. (2007). Ring1B is crucial for the regulation of developmental control genes and PRC1 proteins but not $X$ inactivation in embryonic cells. J. Cell Biol. 178, 219-229.

Li, X., Isono, K., Yamada, D., Endo, T. A., Endoh, M., Shinga, J., MizutaniKoseki, Y., Otte, A. P., Casanova, M., Kitamura, H. et al. (2011). Mammalian polycomb-like Pcl2/Mtf2 is a novel regulatory component of PRC2 that can differentially modulate polycomb activity both at the Hox gene cluster and at Cdkn2a genes. Mol. Cell. Biol. 31, 351-364.

Maeder, M. L., Thibodeau-Beganny, S., Osiak, A., Wright, D. A., Anthony, R. M., Eichtinger, M., Jiang, T., Foley, J. E., Winfrey, R. J., Townsend, J. A. et al. (2008). Rapid "open-source" engineering of customized zinc-finger nucleases for highly efficient gene modification. Mol. Cell 31, 294-301.

Manfroid, I., Delporte, F., Baudhuin, A., Motte, P., Neumann, C. J., Voz, M. L., Martial, J. A. and Peers, B. (2007). Reciprocal endoderm-mesoderm interactions mediated by fgf 24 and fgf 10 govern pancreas development. Development 134, 4011-4021.

Meng, X., Noyes, M. B., Zhu, L. J., Lawson, N. D. and Wolfe, S. A. (2008) Targeted gene inactivation in zebrafish using engineered zinc-finger nucleases. Nat. Biotechnol. 26, 695-701.

Nagayoshi, S., Hayashi, E., Abe, G., Osato, N., Asakawa, K., Urasaki, A., Horikawa, K., Ikeo, K., Takeda, H. and Kawakami, K. (2008). Insertional mutagenesis by the Tol2 transposon-mediated enhancer trap approach generated mutations in two developmental genes: tcf7 and synembryn-like. Development 135, 159-169.

Nambiar, R. M., Ignatius, M. S. and Henion, P. D. (2007). Zebrafish colgate/hdac1 functions in the non-canonical Wnt pathway during axial extension and in Wnt-independent branchiomotor neuron migration. Mech. Dev. 124, 682-698.

Narita, T., Sasaoka, S., Udagawa, K., Ohyama, T., Wada, N., Nishimatsu, S. Takada, S. and Nohno, T. (2005). Wnt10a is involved in AER formation during chick limb development. Dev. Dyn. 233, 282-287.

Neto, A., Mercader, N. and Gomez-Skameta, J. L. (2012). The osr1 and osr2 genes act in the pronephric anlage downstream of retinoic acid signaling and upstream of $w n t 2 b$ to maintain pectoral fin development. Development 139 301-311.

Ng, J. K., Kawakami, Y., Buscher, D., Raya, A., Itoh, T., Koth, C. M., Rodriguez Esteban, C., Rodriguez-Leon, J., Garrity, D. M., Fishman, M. C. et al. (2002). The limb identity gene Tbx5 promotes limb initiation by interacting with Wnt2b and Fgf10. Development 129, 5161-5170.

Nomura, R., Kamei, E., Hotta, Y., Konishi, M., Miyake, A. and Itoh, N. (2006). Fgf16 is essential for pectoral fin bud formation in zebrafish. Biochem. Biophys. Res. Commun. 347, 340-346.

Norton, W. H., Ledin, J., Grandel, H. and Neumann, C. J. (2005). HSPG synthesis by zebrafish Ext2 and Extl3 is required for Fgf10 signalling during limb development. Development 132, 4963-4973.

Paro, R. (1995). Propagating memory of transcriptional states. Trends Genet. 11, 295-297.

Picker, A., Roellig, D., Pourquie, O., Oates, A. C. and Brand, M. (2009). Tissue micromanipulation in zebrafish embryos. Methods Mol. Biol. 546, 153172

Pietersen, A. M., Evers, B., Prasad, A. A., Tanger, E., Cornelissen-Steijger, P., Jonkers, J. and van Lohuizen, M. (2008). Bmi1 regulates stem cells and proliferation and differentiation of committed cells in mammary epithelium. Curr. Biol. 18, 1094-1099.

Pirrotta, V. (1997). PcG complexes and chromatin silencing. Curr. Opin. Genet Dev. 7, 249-258.

Popperl, H., Rikhof, H., Chang, H., Haffter, P., Kimmel, C. B. and Moens, C. B. (2000). lazarus is a novel pbx gene that globally mediates hox gene function in zebrafish. Mol. Cell 6, 255-267.
Prykhozhij, S. V. and Neumann, C. J. (2008). Distinct roles of Shh and Fgf signaling in regulating cell proliferation during zebrafish pectoral fin development. BMC Dev. Biol. 8, 91

Rau, M. J., Fischer, S. and Neumann, C. J. (2006). Zebrafish Trap230/Med12 is required as a coactivator for Sox9-dependent neural crest, cartilage and ear development. Dev. Biol. 296, 83-93.

Reifers, F., Bohli, H., Walsh, E. C., Crossley, P. H., Stainier, D. Y. and Brand, M. (1998). Fgf8 is mutated in zebrafish acerebellar (ace) mutants and is required for maintenance of midbrain-hindbrain boundary development and somitogenesis. Development 125, 2381-2395.

Roehl, H. and Nusslein-Volhard, C. (2001). Zebrafish pea3 and erm are general targets of FGF8 signaling. Curr. Biol. 11, 503-507

Sauvageau, M. and Sauvageau, G. (2010). Polycomb group proteins: multifaceted regulators of somatic stem cells and cancer. Cell Stem Cell 7, 299-313.

Sleptsova-Friedrich, I., Li, Y., Emelyanov, A., Ekker, M., Korzh, V. and Ge, R. (2001). fgfr3 and regionalization of anterior neural tube in zebrafish. Mech. Dev. 102, 213-217

Sparmann, A. and van Lohuizen, M. (2006). Polycomb silencers control cell fate, development and cancer. Nat. Rev. Cancer 6, 846-856.

Stock, J. K., Giadrossi, S., Casanova, M., Brookes, E., Vidal, M., Koseki, H., Brockdorff, N., Fisher, A. G. and Pombo, A. (2007). Ring1-mediated ubiquitination of $\mathrm{H} 2 \mathrm{~A}$ restrains poised RNA polymerase $\mathrm{II}$ at bivalent genes in mouse ES cells. Nat. Cell Biol. 9, 1428-1435.

Surface, L. E., Thornton, S. R. and Boyer, L. A. (2010). Polycomb group proteins set the stage for early lineage commitment. Cell Stem Cell 7, 288-298.

ten Berge, D., Brugmann, S. A., Helms, J. A. and Nusse, R. (2008). Wnt and FGF signals interact to coordinate growth with cell fate specification during limb development. Development 135, 3247-3257

Trojer, P., Cao, A. R., Gao, Z., Li, Y., Zhang, J., Xu, X., Li, G., Losson, R., Erdjument-Bromage, H., Tempst, P. et al. (2011). L3MBTL2 protein acts in concert with PcG protein-mediated monoubiquitination of $\mathrm{H} 2 \mathrm{~A}$ to establish a repressive chromatin structure. Mol. Cell 42, 438-450.

van der Stoop, P., Boutsma, E. A., Hulsman, D., Noback, S., Heimerikx, M., Kerkhoven, R. M., Voncken, J. W., Wessels, L. F. and van Lohuizen, M. (2008). Ubiquitin E3 ligase Ring1b/Rnf2 of polycomb repressive complex 1 contributes to stable maintenance of mouse embryonic stem cells. PLOS ONE 3 e2235.

Vidal, M. (2009). Role of polycomb proteins Ring1A and Ring1B in the epigenetic regulation of gene expression. Int. J. Dev. Biol. 53, 355-370

Vire, E., Brenner, C., Deplus, R., Blanchon, L., Fraga, M., Didelot, C., Morey, L., Van Eynde, A., Bernard, D., Vanderwinden, J. M. et al. (2006). The Polycomb group protein EZH2 directly controls DNA methylation. Nature 439, 871-874.

Voncken, J. W., Roelen, B. A., Roefs, M., de Vries, S., Verhoeven, E., Marino, S., Deschamps, J. and van Lohuizen, M. (2003). Rnf2 (Ring1b) deficiency causes gastrulation arrest and cell cycle inhibition. Proc. Natl. Acad. Sci. USA 100, 2468-2473.

Wang, H., Wang, L., Erdjument-Bromage, H., Vidal, M., Tempst, P., Jones, R. S. and Zhang, Y. (2004). Role of histone H2A ubiquitination in Polycomb silencing. Nature 431, 873-878

Waxman, J. S., Keegan, B. R., Roberts, R. W., Poss, K. D. and Yelon, D. (2008). Hoxb5b acts downstream of retinoic acid signaling in the forelimb field to restrict heart field potential in zebrafish. Dev. Cell 15, 923-934.

Westerfield, M. (2000). The Zebrafish Book (4th edn). Eugene, OR: University of Oregon Press

Yelon, D., Ticho, B., Halpern, M. E., Ruvinsky, I., Ho, R. K., Silver, L. M. and Stainier, D. Y. (2000). The bHLH transcription factor hand2 plays parallel roles in zebrafish heart and pectoral fin development. Development 127, 2573-2582.

Yu, M., Mazor, T., Huang, H., Huang, H. T., Kathrein, K. L., Woo, A. J., Chouinard, C. R., Labadorf, A., Akie, T. E., Moran, T. B. et al. (2012). Direct recruitment of polycomb repressive complex 1 to chromatin by core binding transcription factors. Mol. Cell 45, 330-343.

Zhou, W., Zhu, P., Wang, J., Pascual, G., Ohgi, K. A., Lozach, J., Glass, C. K. and Rosenfeld, M. G. (2008). Histone H2A monoubiquitination represses transcription by inhibiting RNA polymerase II transcriptional elongation. Mol. Cell 29, 69-80. 